\title{
Preface to The Eagle Feather 2010
}

Editor-in-Chief: Gloria C. Cox, Honors College and Department of Political Science, College of Arts and Sciences

Editor: Susan Brown Eve, Honors College and Department of Sociology, College of Public Affairs and Community Service

It is with great pride that we present the seventh issue of The Eagle Feather: A

Publication for Undergraduate Scholars (TEF). We are delighted that the journal continues to grow, making this our largest issue ever with 34 articles by undergraduate scholars. Since the inaugural issue, 142 articles have been published in The Eagle Feather. This edition includes articles by UNT students who worked with their faculty mentors during the 2009-10 academic year, as well as special sections by the College of Education, the College of Engineering, and the College of Visual Arts and Design.

This issue also includes the proceedings of two Research Experiences for Undergraduates (REU) that took place on the UNT campus in summer 2010. REUs, which are funded by the National Science Foundation, bring together students from several universities for intense work on research. First, we are publishing the proceedings of the Political Science REU conducted by Professors John Ishiyama and Michael Greig who taught techniques of quantitative research to several fine scholars who studied peace and conflict issues. Second, for the fourth consecutive year, we are publishing the proceedings of the Anthropology REU. The Anthropology Department's NSF REU grant was renewed in 2009, and under the able direction of Professors Doug Henry and Beverly Davenport, several excellent students learned and fine tuned their research skills. We look forward to continued collaboration with the faculty and the talented undergraduates in both of these great programs. 
In sum, this edition of The Eagle Feather includes the work of individual authors, departmental scholars, and REU students. We have come a long way since the first edition of The Eagle Feather, which contained just six student-authored articles.

The 2010 issue of The Eagle Feather

Our tradition is that the first article in each edition of The Eagle Feather is the keynote address from the year's University Scholars Day luncheon. In 2010, we were honored to have Dr. Melinda Levin, Professor, Chair, and Division Head in the Department of Radio, Television, and Film, as our Keynote Speaker. Dr. Levin talked about her own exciting research, which includes traveling the globe as a videographer and documentary producer to film the great rivers of the world. We are proud to publish her remarks, which were both interesting and informative.

As in previous years, the student-authored articles in this edition are broadly representative of the humanities, social sciences, and natural sciences in the schools and colleges at the University of North Texas. UNT's young scholars continue to do an excellent job of addressing major world and societal issues in their research. In the social sciences, Henry Pascoe (Department of Political Science, College of Arts and Sciences, and Honors College) analyzes public opinion in Costa Rica. Clara Benson (Department of Sociology, College of Public Affairs and Community Service, and Honors College) considers the effectiveness of the capitalist model of development as it applies to emerging economies. Desiree Hubby (Department of Political Science, College of Arts and Sciences, and Honors College) deals with the subject of development as it applies to the BRIC nations (Brazil, Russia, India, and China).

Three articles come from the behavioral sciences, including the work of Kristen Kettler (Department of Psychology, College of Arts and Sciences, and Honors College), who studied the cardiovascular risk in college students. From the Department of Speech and Hearing Sciences, 
Martin Smith (College of Arts and Sciences, Honors College) deals with guardianship issues for adults with developmental disabilities. Finally, Sara N. Montejano (Department of Teacher Education and Administration, College of Education, Honors College) researched cultural awareness in a community of scholars.

From the humanities, this issue of The Eagle Feather has three interesting papers, all from students in the Department of English in the College of Arts and Sciences. We begin with Honors College student Megan Trotter's research on the nature of sovereignty and the female intellectual in Milton's Paradise Lost. Darby Dyer deals with the matter of mental illness among writers, including case studies of Sylvia Plath and Charlotte Perkins Gilman. The final paper from the humanities is the work of Emily Vincent (Honors College), whose paper discusses motherhood and masculinity in the Flapper Era.

This edition of the journal includes three special sections, representing the Departments of Electrical Engineering and of Computer Science and Engineering in the College of Engineering; the Department of Art Education and Art History in the College of Visual Arts and Design, and the Department of Teacher Education and Administration in the College of Education. Jennifer Williams and David Bratton (both of the Department of Electrical Engineering, and Aaron Jones (Department of Computer Science and Engineering) discuss their Undergraduate Research Initiative project, which involved building and flying a drone under the flight control system they designed. Their paper contains photographs of the plane, both before and after its inaugural flight. David Thomas and Charisse Weston (both of the Department of Art Education and Art History) introduce the section containing papers from undergraduate scholars in Art History. S. M. Santayana (Department of Art Education and Art History, College of Visual Arts and Design, and Honors College) discusses Tibetan Buddhism in her study of 
Avalokitesvara. Kelly Bevin Butler (Department of Art Education and History, College of Visual Arts and Design) researched the silencing of bells as an exercise of power in Medieval Spain, while Lauren Hirsch (Department of Art Education and Art History, College of Visual Arts and Design, and Honors College) researched women and printmaking.

The Eagle Feather also includes papers from the College of Education, each of them focusing on a different aspect of education. Their faculty mentor, Dr. Jeanne Tunks, introduces the papers from her four students. Vanessa Sampogna Western (Department of Teacher Education and Administration) researched assessment issues, while Rachel Leslie (Department of Curriculum and Instruction) studied growth plans in kindergarten classrooms. Monica Daniel (Department of Teacher Education and Administration) writes about the role of reading in education, and Nikki Brookshire (Department of Teacher Education and Administration) researched the effects of African American parental involvement in the success of children.

The remaining articles in this year's Eagle Feather are the proceedings of two National Science Foundation Research Experiences for Undergraduates (REU) that took place at UNT in summer 2010. Professors John Ishiyama and Michael Greig introduce papers from the undergraduate political science scholars who came to UNT this summer to learn sophisticated quantitative research techniques. Professor Beverly Davenport and David Franco then introduce the papers from the scholars who studied at UNT as part of the Anthropology REU. Both the Political Science and Anthropology students lived in Honors Hall, which added to their sense of community and enjoyment while they were studying at UNT.

In addition to students who publish in The Eagle Feather, other Honors students toil in the trenches as student associate editors, and we want to express our gratitude to them for the patience, attention to detail, and sense of responsibility they brought to their work. That we were 
able to complete the editing for such a large volume of papers more or less on time is due in no small part to their daily diligence and good-humored patience. We send a messages of thanks to Melodi Baybordi, (Studio Art, College of Visual Arts and Design, and Honors College); David Claire (General Studies, College of Arts and Sciences, and Honors College); Daphne Glasgow (Department of Radio, Television and Film, Department of Foreign Languages and Literatures, College of Arts and Sciences, and Honors College); Elliott Kidd (Department of English and Department of History, College of Arts and Sciences, and Honors College); Ryeshia Jackson (Department of Psychology, College of Arts and Sciences, and Honors College); Jonathan Holman (Broadcast Media, Mayborn School of Journalism, and Honors College); and Megan Storie (Radio, Television and Film, College of Arts and Sciences, and Honors College).

We also want to express our gratitude to the University Libraries, especially Dr. Martin Halbert, Dean of University Libraries, whose strong and enthusiastic support for The Eagle Feather and our efforts epitomize the ideal of working in a collaborative manner for the good of UNT and its students. As always, members of the Multimedia Development Laboratory team of the Libraries have transformed the articles we sent over into the beautiful issue you see before you. Thanks to those who work such wonders, including Neena Weng, Laboratory Manager; William Hicks, Technology Coordinator; Dianne Jansing, Project Assistant; and Mary Lauren Maxwell, Student Assistant.

While putting together The Eagle Feather is hard work, it is also a pleasure, as it reflects the success UNT has achieved in creating opportunities for our students to learn about research and develop research skills and experience. We take much pride in bringing you the 2010 edition of The Eagle Feather, and hope that reading it is a pleasure that reveals to you the great talent 
and accomplishments of UNT students and those from other colleges and universities who study here as part of our undergraduate research programs and opportunities.

The Editors 